\title{
Roles for developing public-private partnerships in centralized public procurement
}

Outi Keränen

Department of Marketing, Oulu Business School, University of Oulu, P.O. BOX 4600, FI90014 University of Oulu, Finland

E-mail address: outi.keranen@,oulu.fi

\begin{abstract}
This study examines the roles actors play to develop public-private partnerships (PPPs) in the context of centralized public procurement and how these roles change during the procurement process. The roles are explored by applying role theory and the typologies of managerial and intermediary roles and by utilizing a triadic approach to distinguish these roles in raw food and home nursing procurement settings. The findings of this study increase the understanding of PPPs by identifying the roles for developing PPP relationships and how these roles are played to reinforce this development in centralized public procurement. Furthermore, the findings contribute to the research on relationship dynamics by showing how actors' roles and the performance of those change and are influenced by the public procurement context and the roles the other actors undertake during the centralized public procurement process. The study yields insights for managers of public and private organizations seeking to develop stronger PPPs and improve public procurement.
\end{abstract}

Keywords: Relationship development, Role, Triadic approach, Public-private partnership, Centralized public procurement 


\section{Introduction}

Public procurement has changed remarkably in the last 30 years. Traditional public procurement that emphasizes transactional exchange and arm's length relationships between public and private organizations (Lian \& Laing, 2004) has confronted challenges to meet modern budgetary restrictions and find effective ways of providing public services with limited resources (Guzmán \& Sierra, 2012; Jacobson \& Choi, 2008; Rees \& Gardner, 2003). Thus, to respond to these requirements, public organizations have come to consider public procurement more strategically by emphasizing new procurement procedures and management models (Erridge \& Greer, 2002; Essig \& Batran, 2005). These procurement reforms and new contracting arrangements reflect the paradigm shift within public administration, which emphasizes reciprocally rewarding partnership relationships and stronger interorganizational collaboration with private organizations (e.g., Erridge \& Greer, 2002; Guzmán \& Sierra, 2012; Lawther \& Martin, 2005).

In literature, public-private partnerships (PPPs) relate to a range of collaborative efforts between public and private organizations (Jamali, 2004). In its narrowest form, PPP refers to a particular type of contractual arrangement between public and private organizations (e.g., Chou \& Pramudawardhani, 2015; Li, Akintoye, Edwards, \& Hardcastle, 2005) that is formed to fund, build, administer and sustain infrastructure (COM $2004327^{1}$ ). Nevertheless, different types of public arrangements from traditional contracting to more innovative procurements (Gidman, Blore, Lorentzen, \& Schuttenbelt, 1995) are suggested to advantage from the characteristics of partnership relationships, for example, shared goals, reciprocity and trust. Therefore, the PPP concept is applied here to understand generally collaborative relationships between public and private organizations (e.g., Erridge \& Greer, 2002; Parker \& Hartley, 2003) and PPP is defined as an institutional arrangement between public and private organizations (Hodge \& Greve, 2007) that includes collaboration to reach shared goals of delivering public services (Jamali, 2004). If properly managed, PPPs tend to expand resource exchange, diminish transaction costs, increase risk sharing, clarify contract specifications and encourage stronger interorganizational collaboration (Erridge \& Greer, 2002) and thereby improve the quality and reliability of public services (Kwak, Chih, \& Ibbs, 2009).

\footnotetext{
${ }^{1}$ Green Paper on public-private partnerships and Community law on public contracts and concessions.
} 
The development of PPPs and applying collaborative procurement procedures within the competitive framework is challenging (Erridge \& McIlroy, 2002; Smyth \& Edkins, 2007) and PPPs are criticized from their inability to reach transparency and cost savings (Kwak et al., 2009). In particular, the legal framework and the culture of public organizations tend to generate high institutional and strategic barriers that induce PPPs to break down prematurely (Erridge \& Greer, 2000; Klijn \& Teisman, 2003). For example, Klijn and Teisman (2003) advise that value differences create problems with joint decision-making and sharing of responsibilities. Therefore, PPPs are supplemented by problems of instability and inadequate relationship quality (Zou, Kumaraswamy, Chung, \& Wong, 2014) that are recognized to emerge from public organizations' tradition of merely reacting to the changes in markets rather than proactively seeking to initiate partnership relationships that engender collaboration and trust (Smyth \& Edkins, 2007).

The trend toward procurement centralization (Karjalainen, 2011) has challenged PPP development by involving in the public procurement process professional public purchaser playing an intermediary role between individual public units managing procurement implementation and private supplier organizations. In the context of centralized public procurement, the public purchaser, the public unit managing procurement implementation and the private supplier organizations thus form a triadic partnership relationship in which they perform particular types of activities, determining their roles (Heikkinen, Mainela, Still, \& Tähtinen, 2007; Kanter, 1994) that assist them to manage their relations (Möller, Rajala, \& Svahn, 2005) and the public procurement process. Nevertheless, these specifically assigned activities make the actors independent organizations, particularly with regard to how they contribute to their partnership relationships and the procurement process. Furthermore, the development of these triadic partnership relationships is dynamic (Gutek, Groth, \& Cherry, 2002); the roles of the actors and the relationships between them tend to change during the procurement process (Li \& Choi 2009), thus increasing actors' uncertainty related to their developmental roles and how they may reinforce their PPP relationships.

Regardless of their managerial importance, research on roles that public and private actors play to strengthen their partnerships relationships during different procurement stages remain an under-research phenomenon. Although the new partnership thinking has changed the requirements of how public and private organizations interact (Lawther \& Martin, 2005) and extensive research exists on factors promoting and inhibiting PPPs (e.g., Chou \& Pramudawardhani, 2015; Jamali, 2004; Li et al., 2005; Zhang, 2005; Zou et al., 2014), the dynamics of interaction between public and private organizations during the centralized 
public procurement process and how the three actors contribute to the development of their triadic partnership relationships need investigation. There are multiple studies employing the concept of role to understand the dynamics of interorganizational relationships (e.g., Anderson, Havila, Andersen, \& Halinen, 1998) by exploring the management of networks (e.g., Heikkinen et al., 2007; Knight \& Harland, 2005) or the role of intermediary in triadic relationship (e.g., Havila, Johanson, \& Thilenius, 2004; Komulainen, Mainela, \& Tähtinen, 2013; Nätti, Pekkarinen, Hartikka, \& Holappa, 2014). Nevertheless, these roles are not inevitably relevant or identical from a relationship development perspective (Tanner, 1999) or they are of limited meaning for PPP relationships.

The purpose of this study is to understand the development of PPPs between the professional public purchaser, the public unit managing procurement implementation and the private supplier organization in centralized public procurement. The study pursues a contribution to the literature of PPPs and the dynamics of triadic relationships by identifying how the roles actors play reinforce the development of PPPs during the centralized public procurement process. Examining these roles is suggested to provide important insights and knowledge for managers of public and private organizations engaging in PPPs to help them develop their partnership relationships and thus deliver reliable and effective public services. This purpose is addressed by two research questions:

What types of roles do actors play to develop PPPs in centralized public procurement?

How do these roles change during a centralized public procurement process?

The remainder of this paper introduces the literature from centralized public procurement and applies role theory to synthesize and categorize the typologies of managerial and intermediary roles from a relationship development perspective and to identify the roles reinforcing the development of PPPs in centralized public procurement. Thereafter, the research methodology is presented, and empirical findings that show how actors developed their PPPs during centralized public procurements of raw food and home nursing are introduced. In the last chapters, the theoretical and managerial implications are discussed, and the evaluation of the study and suggestions for future research are presented. 


\section{Centralization of public procurement}

In public procurement, public organizations purchase for public consumption (Weiss, 1993) by adhering to national and multinational procurement laws and regulations that are imposed by national governments or multinational legislative authorities (Kuusniemi-Laine \& Takala, 2007 p. 23). Public procurement is a standard governmental function (Brown \& Potoski, 2003) through which public authorities undertake public services (Erridge \& McIlroy, 2002).

Public organizations' strategic and purchasing goals are different from goals in private markets (Larson, 2009); private firms are generally centered on profit maximization, whereas public purchasers must integrate different ethical, democratic, professional and person-related goals into their procurement procedures (Kernaghan, 2003; Purchase, Goh, \& Dooley, 2009). Public procurement is thus complex, ambiguous (Rainey \& Bozeman, 2000) and requires a purchaser to merge a number of competing priorities. That is, most public purchasers struggle to provide more for taxpayers for less cost, combined with the urge to emphasize transparency and the regulatory framework of public procurement and simultaneously attend to the public interest (Erridge \& McIlroy, 2002).

In attempting to resolve these conflicting goals and provide public services effectively, many governments are turning to the centralization of public procurement. Public procurement centralization refers to the utilization of centralized framework agreements, and it refers to the centralization of activities up to and including the formation of a contract for public units and the management of that contract (Karjalainen, 2011). In this setting, the public procurement process is separated into stages, from which a third actor - professional public purchaser - performs contracting by determining whether something is suitable for contracting, determining whether there is a private partner from which to purchase and then executing the bidding (Brown \& Potoski, 2003). Tasks related to procurement implementation are then viewed as decentralized to individual public units (Karjalainen, 2011). In the implementation stage, public managers monitor and estimate the procurement implementation and determine whether the private partner has fulfilled its responsibilities (Brown \& Potoski, 2003). This type of centralization can bring purchasing synergy benefits, for example, by helping attain lower unit costs by increasing market power, sharing procurement knowledge and establishing joint practices to implement procurements (Trautmann, Bals, \& Hartmann, 2009).

Nevertheless, centralization brings challenges. In the context of centralized public procurement, three actors interact repeatedly to collaborate under a particular governmental 
contract to deliver public services (Kwak et al., 2009; Madhavan, Gnyawali, \& He, 2004; Simmel, 1950; Thibaut \& Kelley, 1959). The centralization thus diminishes public organizations' direct control of the quality of public services (van Iwaarden \& van der Valk, 2013). Furthermore, the centralization increases purchasing quantities and creates governmental invitations for tender wherein merely few private firms are capable of fulfilling the requirements (Caldwell et al., 2005). In addition, centralized procurement tends to engender attitudinal problems, control issues and difficulties in exchanging knowledge, which slows down responding to the diversity of needs of individual public units that are served by professional public purchasers (Erridge, 2007; Cousins, Lamming, Lawson, \& Squire, 2008).

\section{Using role theory to understand roles reinforcing the development of PPPs}

Role theory explains the roles, or patterns of behavior, that are characteristic of actors and their contexts (Biddle, 2013). From a functionalist perspective, roles stem from sets of shared and normative expectations related to particular positions (Biddle, 1986). The concepts 'role' and 'position' are thus inseparable (Anderson et al., 1998), and actors play the role or multiple roles required by their informal or formal positions (Levinson, 1959; Montgomery, 1998). That is, position involves sets of roles that are provoked by particular types of context (Merton, 1957; Biddle, 1986). Therefore, the role is determined here to relate to PPP development activities rather than defining that role through positions. The scholars of Industrial Marketing and Purchasing (IMP) group (e.g., Ford et al., 1998; Håkansson \& Snehota, 1995) suggest these developmental activities, for example resource exchange and adaptations, to form mutual relationships between reciprocally committed actors through the chain of interaction episodes - sequence of acts and counteracts (Holmlund \& Törnroos, 1997).

Interactionist role theorists distinguish role-related performance developed through interaction and how actors understand and interpret their and others' behavior (Biddle, 1986). In this view, actors jointly determine what forms the particular role (Ashforth, 2000), thus stressing the power of actors to interpret, organize, modify and create roles (Heikkinen et al., 2007). Rather than just conforming to the norms of a given institutional context (Montgomery, 1998), roles originate from creative participation in a reciprocally adaptive system of activities (Anderson et al., 1998). Therefore, the roles hold more-constructive characteristics by describing actors' intentions in situations, the meanings they provide for 
these situations and preferences for changing them by playing particular types of roles (Anderson et al., 1998; Heikkinen et al., 2007). Roles are thus defined as behavioral patterns (Turner, 1990 p. 88), establishing the foundation for relationship development, and they are perceived to emerge from both the expectations of others and intentional meanings that are changed by the actors themselves (Heikkinen et al., 2007).

In search for roles reinforcing the development of PPPs, the typologies of managerial and intermediary roles in interorganizational context are categorized into three types of role groups with an emphasis on how they contribute to the relationship development process. Relationship development tends to start with phases in which actors search potential exchange partners and determine their mutual goals (Batonda \& Perry, 2003). Thus, a liaison, establishing the net of external relationships by linking the organization to its environment (Mintzberg, 1980), and a webber, who recruits the net by deciding, which actors are requested to join (Heikkinen et al., 2007), are proposed important for the initiation of partnership relationship. Similar types of broker and agent roles are architect, seeking actors with desirable expertise and attracting them into the relationship, lead operator, which is perceived as formally connecting actors together (Snow, Miles \& Coleman 1993), and network structuring agent, who influences the structure of exchange relationships (Knight \& Harland, 2005). In the literature of intermediary roles, the third actor is detected to connect actors (e.g., Komulainen et al., 2013; Peng \& Ilinitch, 1998) by bridging the cultural and geographical gaps between the other two actors (e.g., El-Ansary \& Stern, 1992; Havila et al., 2004; Li \& Choi, 2009).

By following the shared goals, relationships grow into the developmental phase in which actors start to work together and the interdependencies and trust between them develop (Dwyer, Schurr, \& Oh, 1987; Kanter, 1994). To foster the development of the triadic partnership relationship, the third actor is recognized to perform rather unique and specific tasks (Havila et al., 2004), for example, by taking the role of promoter, who promotes relationship development (Halinen \& Salmi, 2001), or of positive boundary spanner (e.g., Perrone, Zaheer, \& McEvily, 2003; Williams, 2002), who refers to the advocate (e.g., Heikkinen et al., 2007; Krapfel, 1985; Tanner, 1999) or ambassador increasing the inward and outward flow of resources (Komulainen et al., 2013). Furthermore, managerial roles that intensify knowledge exchange are important for relationship development, for example, a monitor, who gathers information from the environment, a spokesman, who transmits information from the organization to its environment (Mintzberg, 1980), an information broker, who sorts, examines and disseminates information within the network, a coordinator, 
who administrates interorganizational activities and manages intra-network relationships, communication and working practices, and a policymaker and implementer, who determines and implements policies (Knight \& Harland, 2005).

Relationship development includes efforts to sustain the partnership relationship, for example, by developing mechanisms for bridging and resolving differences (Dwyer et al., 1987; Kanter, 1994). The third actor is identified to support relationship development by playing the role of unifier, who influences the triadic relationship to keep it together (Salo, Tähtinen, \& Ulkuniemi, 2009) or mediator, who keeps the three actors together by defending their unity against the interests of single parties (e.g., Dubois \& Fredriksson, 2008; Holmen \& Pedersen, 2003; Komulainen et al., 2013; Simmel, 1950). Additional roles facilitating the relationship development include the managerial role of caretaker, who nurtures the relationship (Snow et al., 1993); compromiser, who tries to prevent conflicts (Heikkinen et al., 2007); disturbance handler, who manages the conflicts arising from relationships with other organizations; negotiator, who negotiates within and between the organizations (Mintzberg, 1980); or arbiter (Wilson \& Millman, 2003) or conciliator, who manages recovery situations (Nätti et al., 2014). In addition, actors can play the generic role of advisor, who provides formal and informal advice to members of the network; innovation facilitator, who promotes process or product innovation (Knight \& Harland, 2005) or value co-creation facilitator (Nätti et al., 2014), who enhances value co-creation in a triadic setting.

Table 1 shows multiple examples addressing the roles of network manager or intermediary from different contexts and with different names. By synthesizing and categorizing this literature from a relationship development perspective, three types of roles are proposed important for PPP development: (1) relationship initiator, (2) relationship builder and (3) relationship facilitator. To ground this categorization empirically and to identify the roles played to develop PPPs in centralized public procurement, a multiple case study is conducted to explore PPPs formed around the centralized public procurements of raw food and home nursing. 
Table 1 Synthesis and categorization of roles from a relationship development perspective.

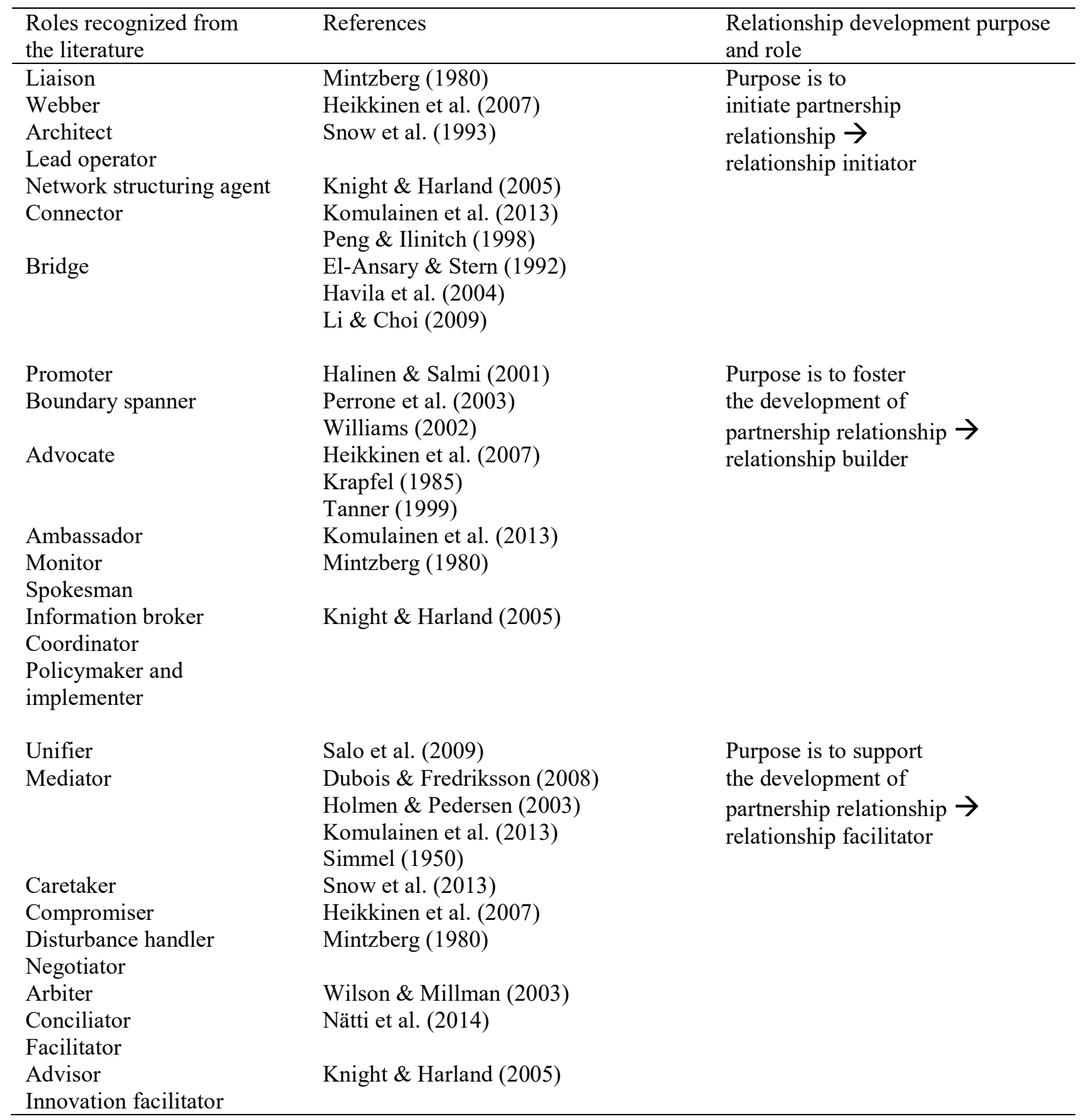

\section{Methodology}

A qualitative multiple case study is conducted to understand the roles reinforcing the development of PPPs and how these roles change during the centralized public procurement process. This method is suitable for establishing holistic understanding of roles played to contribute to the development of PPPs (Stake, 1995 p. 47) because it permits the examination of a phenomenon, which is difficult to separate from its context, but necessary to explore within it to understand the dynamics of this setting (Halinen \& Törnroos, 2005). That is, rolerelated performance affects and is affected by the relationship structure and context of a 
relationship (Anderson et al., 1998). In particular, the procurement type and the organization of public procurement are suggested as affecting how actors manage their selling and buying processes and reflecting the need for different types of activities determining actors' developmental roles. Therefore, this study explores both standardized product procurement and more diversified service procurement in Finland, implemented by adhering to the public procurement legislation of EU (Directive 2004/18/EC ${ }^{2}$ ), to increase learning from roles required in PPPs (Stake, 1995 p. 4).

First, a raw food-related PPP between a public procurement unit and public units providing catering services from a federation of municipalities $\mathrm{X}$ and a private food supplier organization is explored to exemplify the standardized procurement type. Raw food is a typical example of a standardized product that is straightforward for public organizations to determine by themselves. In food procurements, products are rather similar, and they must fulfill specific food legislation and nutritional criteria. In the federation of municipalities X, the majority of standardized public procurements are centralized for a single public procurement unit. Thus, the public procurement unit's responsibilities related to purchasing raw food items for public units providing catering services in the federation of municipalities $\mathrm{X}$. The public procurement unit has the higher procurement expertise required by national and EU regulations, but its knowledge related to different procurement types is imperfect; therefore, the members of individual public units help the procurement unit determine specific procurement terms. Furthermore, given the need for large food quantities and the requirements of fast supply, researched raw food markets are highly limited for the federation of municipalities X. Thus, their bid processes are dominated by two large and intensively competitive firms.

Second, a home nursing-related PPP between a public procurement unit performing contracting, a public unit managing procurement implementation and a private home nursing provider is examined to demonstrate the partial outsourcing of public home nursing services in town Q. Given the unique characteristics of services that make them inseparable from their providers, the quality and practices of how private service providers produce their home nursing tend to differ, although they must adhere to laws related to the elderly and their nursing. In town $\mathrm{Q}$, the public procurement unit specializes in procurements of public

\footnotetext{
2 Directive 2004/18/EC of the European Parliament and of the Council of 31 March 2004 on the coordination of procedures for the award of public works contracts, public supply contracts and public service contracts.
} 
services for the elderly; therefore, their knowledge of home nursing is strong. Nonetheless, Finnish home nursing markets are emerging and they are a new territory for public procurement, thus affecting the experience and expertise of both public organizations and private home nursing providers from home nursing procurements.

The primary data were acquired through 16 thematic individual or pair interviews (Appendix A) (Arksey \& Knight, 1999), including six interviews related to the raw food and ten to home nursing procurement (Table 2). The interviewees included 20 informants from different units of public and private supplier organizations, and their selection rested on snowball sampling (Biernacki \& Waldorf, 1981). The responsibilities of the interviewees included the contracting and procurement implementing activities and thus interviewing them offered good insights into the roles reinforcing the development of PPPs in centralized public procurement and how these roles change in different procurement stages. 
Table 2 Primary data of the study.

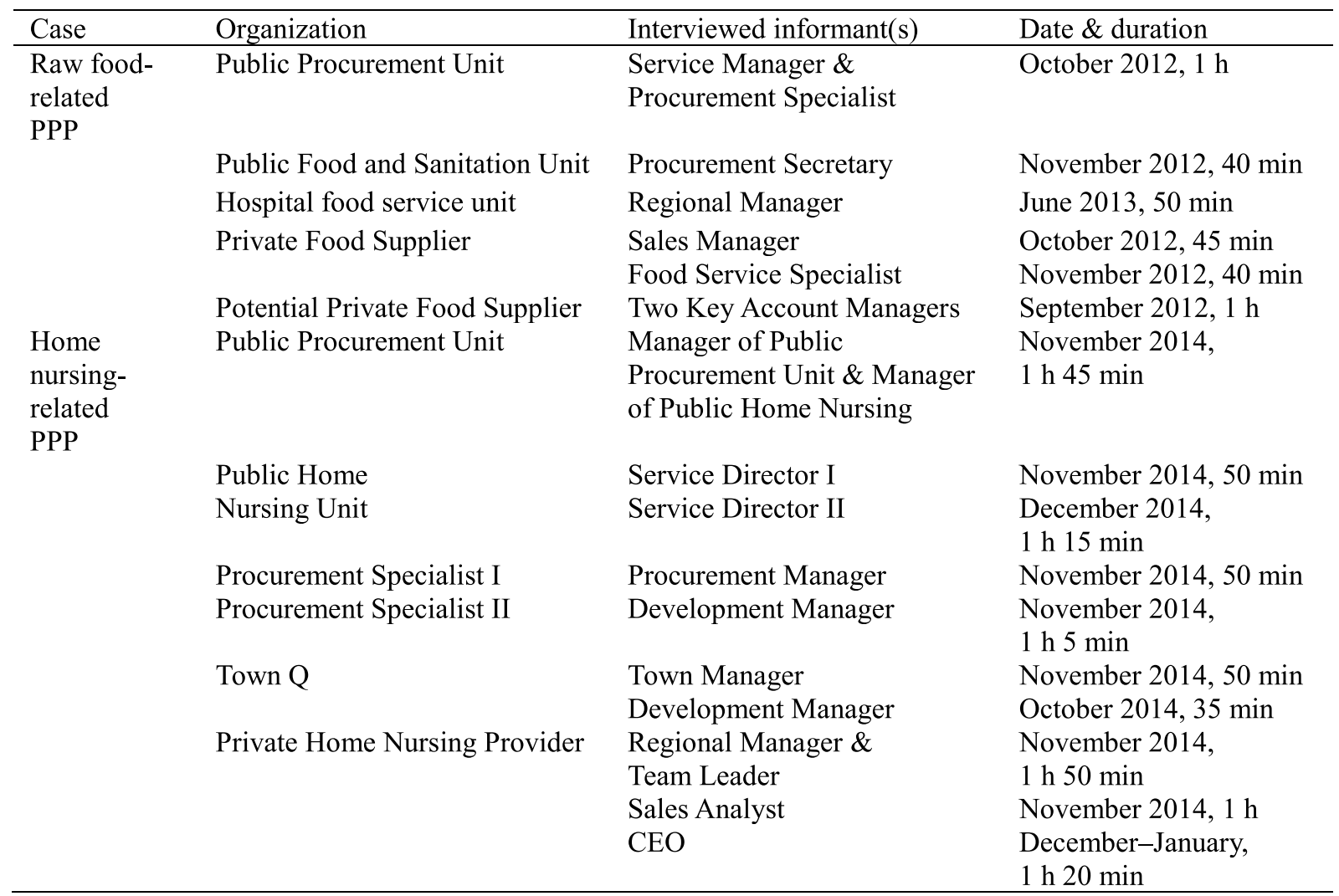

The findings of the interview data were supported and triangulated (Denzin, 1978) by using data from the web pages of explored organizations, establishing understanding of their business logics and responsibilities, and multiple public procurement reports that gave insights into different types of collaborative efforts during the procurement process. In addition, related to the raw food procurement, the data included the thematic interview of a food industry expert and multiple site visits to the premises of a potential private food supplier to increase understanding of the structure of food industry and of other contextual factors affecting the food-related PPP. The data from the home nursing-related PPP featured regional newspaper articles and industry reports related to the state of home nursing markets. Furthermore, the information about procurement regulations and from four public procurement-related seminars held by national EU procurement professionals and lawyers helped the researcher establish a general understanding of procurement procedures and practices of the EU.

The study utilizes an abductive strategy; thus, continuous interplay between the theory and empirical data was stressed to expand understanding from both of them (Dubois \& Gadde, 2002). In the beginning of the research process, although the researcher had preliminary theoretical understanding from the research phenomenon, the interviews related 
to the raw food procurement steered the researcher to establish its tentative theoretical categorization from intermediary roles, which reflects the process to rely more on induction than deduction (Järvensivu \& Törnroos, 2010). Thereafter, the empirical findings from the home nursing-related PPP directed the researcher to expand the theoretical categorization with other role typologies and then confront this revised framework with empirical data to understand how the development of PPPs is reinforced in centralized public procurement.

Aligned with the abductive research strategy, the researcher analyzed the empirical data thematically (Miles \& Huberman, 1994) with the help of theoretical categorization, although new results were permitted to emerge from the data. Thus, the beginning of analysis was data-driven; it began by exploring the content of interviews and mind mapping inductively the activities the three actors performed during the different stages of public procurement from the interviewees' perspective. Then, the researcher compared the mind maps within the individual procurement contexts to identify similarities and reassert the importance of performed activities. Thereafter, the researcher employed the theoretical categorization to address the meaning of these activities concerning PPP development and categorize them into the suggested role categories. The empirical findings renewed the tentative theoretical categorization by showing explicitly the types of roles and how they were played to develop PPPs during different public procurement stages. Finally, the researcher combined the results from the two public procurements to identify how public procurement type and other contextual factors affected the roles reinforcing the development of PPPs in centralized public procurement.

\section{Empirical findings from roles for developing PPPs in centralized public procurement}

This chapter identifies the roles the three actors played to develop their PPPs in centralized raw food and home nursing public procurements and how these roles changed in the contracting and procurement implementation stages.

\subsection{Roles in the public procurement of raw food}

\subsubsection{Contracting}

In the federation of municipalities $\mathrm{X}$, standardized public procurements are centralized for a single procurement expert unit whose primary responsibilities relate to contracting of those 
procurements. In the raw food procurement, the public procurement unit purchased raw food items for the preparation of individual public units that provide catering services for public organizations, for example, public schools, retirement homes and hospitals. The public procurement unit thus initiated the food-related PPP by formally connecting the three actors together. The procurement unit prepared the tendering reports and employed an open procurement procedure, permitting national and international private food suppliers to receive tendering reports and submit their offers freely (Lindskog, Brege, \& Brehmer, 2010) to evaluate the offers. Thereafter, the public procurement unit influenced the PPP relationship by selecting a suitable private partner and signing the contract with it. This contract related to providing raw food within the federation of municipalities X during 2012-2016 and it included specific instructions, particularly for the food supplier of how to deliver food items effectively and thus assist public units to provide better catering services.

The public procurement unit started contracting by informing the net of potential private food suppliers through an electronic system about their raw food procurement and increasing their attractiveness as a feasible exchange partner. Thereafter, the procurement unit invited interested food suppliers to submit questions, share freely their thoughts on the rigor of the tendering reports and reveal terms not reasonable from their perspective. These activities show the public procurement unit's interest in bridging the needs of the three actors, establish shared understanding of the procurement implementation, and clarify its terms.

It creates shared understanding -- Then, their needs and our needs cross and that creates good results.

(Service Manager, Public Procurement Unit)

The collaborative efforts from the public procurement unit improved contracting and by increasing reciprocity established a basis for PPP development. Checking the unambiguity and potential mistakes of tendering reports was described as essential to finishing the procurement on time and reducing the costs of contracting. That is, sharing technical information helped confirm that the tendering reports were fair and thus mitigated the risks of complaints and the number of redundant rejections.

Through technical dialog, it is possible to rectify potential mistakes of tendering reports prior to their release. It saves time and I think it is then fair.

(Procurement Secretary, Public Food and Sanitation Unit) 
Furthermore, the interaction prior to the release of request for quotation (RFQ) reduced the unnecessary technicality of contracting and established longed-for informal interpersonal communication between the public procurement unit and the potential private food suppliers.

It is possible to purchase entirely through electronic systems. It is, though, then too mechanical, and it requires that the interaction between the parties happen somewhere; thus, there is this technical dialog. Otherwise, the link to everyday life vanishes.

(Procurement Specialist, Public Procurement Unit)

The interpersonal communication increased the public procurement unit's trust toward potential partners' capabilities to satisfy individual public units' needs and created initial bonding that facilitated discussions during the procurement implementation stage by reducing the threshold of contacting the partner.

I need to show for individual public organizations where they need to purchase, and I must confirm that those firms that I suggest are the kind of firms that can serve public units' needs.

(Procurement Specialist, Public Procurement Unit)

It is always easier to contact the person that you already know.

(Food Service Specialist, Private Food Supplier)

Although the food procurement included largely standardized items that were straightforward to determine, the knowledge of the public procurement unit about specific food attributes and diverse user needs was described as insufficient; the procurement unit is more specialized in procurement regulations and procedures and in how to implement contracting. Therefore, private food suppliers and the group of different public units providing catering services from the federation of municipalities X facilitated the PPP initiation by providing information required to finish contracting effectively. For example, food suppliers helped the public procurement unit by sharing their market knowledge on the food industry and confirming that most of the suppliers can provide the food items the procurement unit was requesting.

In technical dialog, things are sort of looked through to see what is really in the markets. -Bidding is then fair for everybody and there is no intentional discrimination.

(Procurement Secretary, Public Food and Sanitation Unit)

Furthermore, stemming from the intensive competition between the two large food suppliers, firms carefully kept tabs on the fairness of contracting practices and influenced the tendering 
reports, which simultaneously helped the public procurement unit clarify the agenda and terms for collaboration and finish contracting on time.

The markets are divided down the middle, and thus they monitor carefully the bidding procedures -- So that everything goes just right and spot on.

(Service Manager, Public Procurement Unit)

You need to bring strongly forward if their terms are unreasonable or if they are challenging for suppliers.

(Key Account Managers I \& II, Potential Private Food Supplier)

The group of public units supported contracting by assisting the public procurement unit during the preparation of tendering reports and influencing the procurement through their food-related knowledge and information about different types of end user needs, for example, children of schools and patients of hospitals.

There are lots of municipalities... It is not possible that everybody sits around the same table. Therefore, there is a kind of main group that structures RFQs, and the others just bring forward their perspectives. Everybody brings forward their expertise, their thoughts from their work community and perspective. I for example need to think of those criteria and requirements that our customers need... They must be taken into consideration when the bidding starts.

(Procurement Secretary, Public Food and Sanitation Unit)

\subsubsection{Procurement implementation}

In the federation of municipalities $X$, the strategy for how public procurement is organized requires the public procurement unit to manage multiple, different types of contracts with private supplier organizations. In the raw food procurement, the public procurement unit was thus largely facilitating the development of the food-related PPP by forming and following the contract. In particular, the procurement unit influenced the collaboration between the private food supplier and individual public units by addressing explicitly in the contract their responsibilities and tasks, which aimed to simplify procurement implementation, and then by controlling their effective realization.

Then, I follow that contract together with the representatives of the municipalities and the experts from the food industry. -- It starts from there that those things that complicate procurement implementation are thought through and how I can, through the contract, simplify the everyday life of those public units.

(Procurement Specialist, Public Procurement Unit). 
The follow-up tasks of the public procurement unit included regular meetings with the private food supplier. In these meetings, the food supplier was required to share information on procurement statistics and significant changes affecting the food deliveries. For example, the actors started negotiations if particular food items were not manufactured anymore.

Furthermore, they involved arbitrating tasks. The interviewees described partners as having specific routines to execute the contract, which was influenced as needed by the public procurement unit. That is, the procurement unit was responsible for settling and negotiating larger problems hindering the procurement implementation and trust between the other two actors of the PPP.

Those reclamations that emerge from the field, most of them do not require response from us. I am just informed about them and they are followed. Then, if something bigger emerges, dialog is held by me.

(Procurement Specialist, Public Procurement Unit)

The follow-up tasks facilitated the collaboration between the private food supplier and individual public units because the trustworthiness of the partner and the collaboration between them was affected by and relied upon how the actors fulfilled their responsibilities. This reflects the relationship governance type of the food-related PPP as the actors are shown to rely on their formal contract, and the development of their PPP rested on respect toward this agreement.

It is pretty simple when the contract begins. -- It is precisely determined through RFQ and the contract what is expected from collaboration.

(Food Service Specialist, Private Food Supplier)

I think the collaboration with these public organizations is dynamic. It works. It is rather explicit. Of course, it depends on how you perform. You can do things either well or badly.

(Sales Manager, Private Food Supplier)

The private food supplier thus took the role of relationship builder and showed its collaborative posture by controlling tightly the quality of its performance. The food supplier kept the public procurement unit and the other public units informed on procurement statistics and forthcoming product updates and delivery changes, which supported smooth food deliveries and affected the costs of procurement implementation and partners' trust toward their capabilities to fulfill given responsibilities. Furthermore, the food supplier had effective conflict resolution mechanisms, and it promptly addressed delivery and other types 
of problems by negotiating settlements and adapting their procedures to the needs of different public units.

Everything needs to work. That is the starting point. The most important thing is to keep the product and the quality, the quality of activities on the rails. -- Then, there is problem solving. If there is a problem, if a product is faulty, it is investigated and then resolved.

(Sales Manager, Private Food Supplier)

Public units providing catering services and placing food orders fostered PPP development by monitoring food deliveries from their side and informing the food supplier about delivery problems. The interviewees indicated that they regularly shared information related to new food products and executed joint testing and recipe tailoring, although doing so required remote adaptations from them.

Monthly purchases are monitored and compared to the purchases of previous years or months. Then, products are regularly looked through and they are tested together... The recipes are considered. -- The supplier is sort of met halfway. It requires little bit more work from us but then we get what we have promised to the customers.

(Procurement Secretary, Public Food and Sanitation Unit)

The knowledge sharing helped public units respond to the needs of their customers and simultaneously increase and sustain their market knowledge, which facilitated the preparation of forthcoming tendering reports and positively affected collaboration.

We talk about their products and test them so that we have prepared material for the next contracting. In that sense, the collaboration is really good.

(Procurement Secretary, Public Food and Sanitation Unit)

For private food suppliers, regular information sharing increased their knowledge about things that are important for public organizations and provided them an opportunity to show the functionality of their products and indirectly affect later bids.

Important things for the public organization might emerge from there. -- Representatives have impact too through their customer interface. -- They show that our products function, which is then brought forward to these work groups that prepare the new tendering reports.

(Key Account Manager II, Potential Private Food Supplier)

Although the actors gained from this type of knowledge exchange and they made adaptations, reciprocity between the actors and joint satisfaction from food-related PPP remained remote. 
The high reliance on the contract indicates the relationship to rest more on contractual governance than on relational dimensions, although some type of proof about relational norms of flexibility emerged from the excerpts.

It is put into the procurement contract terms that reporting happens at intervals of three months. -- But if neither party sees it necessary, then we talk [to determine] whether it is necessary to meet.

(Procurement Specialist, Public Procurement Unit)

\subsection{Roles in the public procurement of home nursing}

\subsubsection{Contracting.}

In town $\mathrm{Q}$, the public procurement unit specializes in determining the public services intended for the elderly and in contracting for these services together with the external procurement expert organization. The public procurement unit therefore initiated the home nursing-related PPP by assessing whether two of the town's home nursing districts are suitable for partial outsourcing and then by managing related contracting tasks. This partnership rested on a contract that related to providing home nursing services in town $\mathrm{Q}$ and determined the shared goals of delivering high-quality home nursing and retaining the elderly's ability to function.

To perform contracting, the public procurement unit took part of the innovative public procurement project that attempted to increase the quality of contracting practices and thereafter the implementation of home nursing. In their tendering reports, rather than input, the procurement unit emphasized purchasing result through a new type of incentive system that was based on a private home nursing provider's promises of performance. This approach affected the general procedures of procurement implementation by creating the need for tighter management and collaboration between different actors, although the public procurement unit did not provide specific instructions on how a private home nursing provider should implement home nursing services. Furthermore, the public procurement unit emphasized the innovativeness of the contracting process by organizing for the first time a technical dialog between them and the group of potential private partners. That is, due to the lack of good examples from partial outsourcing of home nursing, the procurement unit felt the need to attract and negotiate with interested service providers and utilize their market knowledge to reform and specify the terms of the RFQ and build the new incentive system. 
Technical dialog is smart, as required knowledge is not entirely living with us. In fact, private home nursing providers refined the tendering reports significantly. -- We received feedback and information from experiences the potential private partners had related to this type of procurement, and based on that, the new incentive system was built.

(Manager of Public Procurement Unit, Public Procurement Unit)

If it is not a routine procurement. I mean, for example, round-the-clock nursing of the elderly, that is purely routine, and its RFQ is straightforward to determine without asking anything from service providers or without having any kinds of technical dialog with anybody. -- But this home nursing, which is not a routine procurement, it is stupid to not have dialog. I think the public procurement unit of town $\mathrm{Q}$ understands this.

(CEO, Private Home Nursing Provider)

Organizing this type of pre-negotiations with potential private partners reflects the reciprocity and interest of the public procurement unit to hear service providers' thoughts and determine a set of shared procurement goals. This created a good platform for PPP development by affecting partners' expectations of future collaboration and trying to prevent redundant disputes to rise during the contracting and procurement implementation stages. In particular, the purpose of technical dialog was to mitigate the risk of complaints by enabling face-to-face interaction that humanized the public procurement unit.

The purpose with this procurement was to facilitate innovation, productivity and collaboration reflecting shared interests between them and us. -- I think the technical dialog increases the threshold of contesting. Then, we are not just a faceless public procurement unit. Instead, we are persons who want to purchase home nursing.

(Manager of Public Procurement Unit, Public Procurement Unit)

It gives realism back and forth. It confirms that these profanities... Requests that are unfeasible. If something like that is put into RFQ, it creates a potential for disputes.

(CEO, Private Home Nursing Provider)

Through technical dialog, private home nursing providers facilitated the efforts of the public procurement unit to initiate the PPP by helping establish shared understanding from procurement goals and terms. For example, from the procurement unit's perspective, the emerging nature of home nursing markets created the lack of knowledge related to the total costs of home nursing and established challenges for the procurement unit to form an effective and rigorous RFQ. Regardless of their efforts, the public procurement unit had problems during the contracting stage, which led first to interruption of the bidding, reforming of tendering reports and then changing the private home nursing provider to a new private partner. Nonetheless, from the private service providers' perspective, a technical 
dialog was an effective channel to affect and improve the reciprocity of RFQ and make the procurement more profitable for both parties.

We influence the contracting, so they will not give us an RFQ that includes demands that increase the price unnecessarily. In that kind of situation, we have a sort of lose-lose situation. -- So they should not put extra terms that authorities are not demanding. If authorities give you particular standards, it is not worthwhile to require extra standards.

(CEO, Private Home Nursing Provider)

Given the strong and highly specialized expertise of the public procurement unit from home nursing and other public services for elderly citizens in town $\mathrm{Q}$, the public unit managing the home nursing implementation was not identified to contribute significantly to contracting and the initiation of a home nursing-related PPP.

\subsubsection{Procurement implementation}

In town $\mathrm{Q}$, the implementation of home nursing was based on the utilization of an incentive system that helped public organizations estimate whether their private partner has fulfilled its promises and performed high-quality home nursing. The inexperience related to the management of the partial outsourcing of home nursing, but general knowledge about home nursing, prompted the public procurement unit to share regularly, but rather informally, knowledge with the private home nursing provider that created joint R\&D between these actors. Thus, instead of being merely the facilitator, who followed the realization of contract, the public procurement unit took more of a relationship builder role.

To perform this professionally and with high goals, it is just not possible to purchase and then close your eyes and start doing something else. You really need to follow and manage this process. -- This new incentive system and the interaction and information sharing it requires.

(Manager of Public Procurement Unit, Public Procurement Unit)

The public procurement unit shared their knowledge on town's home nursing practices to reach their mutual goals to improve the cost-effectiveness of home nursing and influence the development of emerging home nursing markets. The private home nursing provider was similarly engaging in the PPP development with the procurement unit by regularly taking part in these strategic negotiations and sharing its inside information from emerging home nursing markets, thereby helping the two public units to benchmark their performance and further improve the new incentive system and public home nursing. This approach shows the actors' 
efforts to engender joint satisfaction, which established a trustful atmosphere between them and a fruitful platform for interorganizational learning and collaboration.

We have shared information for example from our own home nursing processes, financial figures. They have done that as well, they told freely about these things. -- We have tried to create win-win situation that with the same information, they can improve their business and we can improve our own home nursing production.

(Manager of Public Procurement Unit, Public Procurement Unit)

Home nursing is dynamic by its nature and includes rapid and unexpected changes in user needs, which required ongoing adapting and intensive communication and knowledge sharing between the public unit managing home nursing implementation and the private home nursing provider. The two actors thus organized monthly meetings to sustain intensive knowledge-sharing routines, to initiate and monitor changes in home nursing plans, and to resolve jointly reclamations and other types of problems. In these meetings, the actors addressed the needs of end users and adapted the offering accordingly, which helped them control the costs and quality of home nursing.

The monthly meetings with the home nursing provider were systematically coordinated and managed by the public unit managing home nursing, which indicates the public unit to play the role of relationship builder. Creating these routines to exchange knowledge and having otherwise tight interaction established a trustful atmosphere between the two actors and therefore facilitated their collaboration.

I coordinate this collaboration and we have a rhythm. We have specific dates in the month when these meetings are held so that processes, invoicing processes, and everything goes forward. It has to be assertive and we developed, not routine, but a good rhythm.

(Manager of Home Nursing, Public Home Nursing Unit)

We have really tight collaboration. We are all the time on the phone related to customers. -We talk about things and even though we do not meet more than once per month, we have really strong collaboration. We bring forward those flaws and they take them really professionally and they do not try to hide them. Therefore, we talk about them honestly and openly.

(Service Manager I, Public Home Nursing Unit)

In turn, the private home nursing provider developed its relationship with the public unit managing home nursing by guaranteeing high-quality performance through tight monitoring and adapting promptly to required changes emerging from the needs of the two public units and individual users. In particular, the home nursing provider encouraged its staff members 
to influence the procedures for how home nursing is performed flexibly, but effectively, and they nominated a nurse to coordinate home nursing in the two outsourced home nursing districts, particularly to enrich their day-to-day communication with the public home nursing unit. Furthermore, the private partner confronted problems proactively. Instead of hiding problems, the home nursing provider brought forward even unpleasant ones with initiative. This improved the partners' trust and the good working atmosphere within the PPP and thus permitted the actors to provide honest, constructive, bidirectional feedback.

It feels that with this home nursing provider, it is possible to develop reciprocal trust... Through their monitoring, they bring forward these unpleasant things and they do not try to hide them. Those things are talked about freely. -- It affects [the relationship] as then it is not necessary to doubt.

(Manager of Home Nursing, Public Home Nursing Unit)

Communication between us is open and I do not have a feeling that if something emerges that I cannot say something or I cannot tell that something happened. -- They have given us constructive criticism, but I have never felt that they think that we cannot do this.

(Regional Manager, Private Home Nursing Provider)

Although the actors lacked experience to manage partial outsourcing, the actors' strong knowledge about home nursing, the dynamic nature of this particular service procurement and the incentive system promoted the development of rather equal PPP between the parties, to which the three actors contributed fairly. By relying more on relational dimensions, particularly shared goals and intensive knowledge exchange that created joint planning and satisfaction, the actors managed to build reciprocally rewarding PPP relationship.

\section{Results and discussion}

The purpose of this study related to identifying the roles reinforcing the development of PPPs and how these roles change during the centralized public procurement process. The theoretical categorization of managerial and intermediary roles from a relationship development perspective and a triadic approach were utilized to explore two centralized public procurements of raw food and home nursing and relate their empirical insights to the existing knowledge on PPPs and relationship dynamics in triads.

The research findings show how actors perform different types of activities, determining their roles that reinforce the PPP development. In particular, to address the research question of what types of roles actors do play to develop PPPs in centralized public 
procurement, three types of roles and the activities these roles include are suggested important during the development of PPP relationships: (1) relationship initiator, (2) relationship builder and (3) relationship facilitator (Table 3). By exploring the ways through which public and private organizations develop their partnership relationships in a centralized public procurement context, the findings increase the understanding of how the members of a triad in a public setting may address different relational dimensions to reach expected procurement goals. This is important as the activities and roles of the actors and their relational structures tend to change during the procurement process (Li \& Choi, 2009; Nätti et al., 2014). That is, by playing specific roles, the actors are suggested to enrich and strengthen their partnership relationship, which facilitates public and private organizations' efforts to provide high-quality services by the most effective, efficient and economic means (e.g., Erridge \& Greer, 2002; Rees \& Gardner, 2003). 
Table 3 Roles for developing PPPs in centralized public procurement.

\begin{tabular}{|c|c|c|c|}
\hline Context & Organization & Contracting & Procurement Implementation \\
\hline \multirow[t]{3}{*}{$\begin{array}{l}\text { Public } \\
\text { procurement } \\
\text { of raw } \\
\text { food }\end{array}$} & $\begin{array}{l}\text { Public } \\
\text { procurement } \\
\text { unit }\end{array}$ & $\begin{array}{l}\text { Relationship initiator } \\
\text { Attracts and invites the net } \\
\text { of interested private } \\
\text { partners to reform RFQ } \\
\text { Formally connects actors } \\
\text { together by bridging the } \\
\text { needs of three actors and } \\
\text { forming contract } \\
\text { Establishes shared } \\
\text { understanding from } \\
\text { collaboration }\end{array}$ & $\begin{array}{l}\text { Relationship facilitator } \\
\text { Addresses explicit } \\
\text { procurement procedures } \\
\text { and follows their realization } \\
\text { to confirm effective } \\
\text { procurement implementation } \\
\text { Arbitrates to sustain trust and } \\
\text { keep the triad together }\end{array}$ \\
\hline & $\begin{array}{l}\text { Private food } \\
\text { supplier }\end{array}$ & $\begin{array}{l}\text { Relationship facilitator } \\
\text { Supports the initiation of } \\
\text { PPP by providing market } \\
\text { knowledge }\end{array}$ & $\begin{array}{l}\text { Relationship builder } \\
\text { Fulfills their responsibilities, } \\
\text { resolves problems promptly } \\
\text { and exchanges knowledge to } \\
\text { reach prompt procurement } \\
\text { implementation and develop } \\
\text { trust } \\
\text { Remote adaptations }\end{array}$ \\
\hline & $\begin{array}{l}\text { Public unit } \\
\text { providing } \\
\text { catering } \\
\text { services }\end{array}$ & $\begin{array}{l}\text { Relationship facilitator } \\
\text { Supports the initiation of } \\
\text { PPP by assisting } \\
\text { contracting and providing } \\
\text { user-related information }\end{array}$ & $\begin{array}{l}\text { Relationship builder } \\
\text { Fulfils their responsibilities } \\
\text { and exchanges knowledge to } \\
\text { reach prompt procurement } \\
\text { implementation } \\
\text { Remote adaptations }\end{array}$ \\
\hline \multirow[t]{3}{*}{$\begin{array}{l}\text { Public } \\
\text { procurement } \\
\text { of home } \\
\text { nursing }\end{array}$} & $\begin{array}{l}\text { Public } \\
\text { procurement } \\
\text { unit }\end{array}$ & $\begin{array}{l}\text { Relationship initiator } \\
\text { Attracts the net of } \\
\text { interested private partner } \\
\text { Supports contracting } \\
\text { innovation by negotiating } \\
\text { with private partners } \\
\text { Formally links actors } \\
\text { together by bridging the } \\
\text { needs of three actors and } \\
\text { forming contract } \\
\text { Establishes shared } \\
\text { understanding from } \\
\text { collaboration }\end{array}$ & $\begin{array}{l}\text { Relationship builder } \\
\text { Addresses general } \\
\text { procurement procedures and } \\
\text { follows their realization to } \\
\text { reach high-quality } \\
\text { procurement implementation } \\
\text { Exchanges knowledge to } \\
\text { reach strategic level goals } \\
\text { and create joint satisfaction }\end{array}$ \\
\hline & $\begin{array}{l}\text { Private home } \\
\text { nursing } \\
\text { provider }\end{array}$ & $\begin{array}{l}\text { Relationship facilitator } \\
\text { Supports the initiation of } \\
\text { PPP by providing market } \\
\text { knowledge }\end{array}$ & $\begin{array}{l}\text { Relationship builder } \\
\text { Intensively coordinates } \\
\text { interaction, exchanges } \\
\text { knowledge and solves } \\
\text { problems proactively to } \\
\text { deliver high-quality } \\
\text { performance and reach } \\
\text { strategic level goals that } \\
\text { create joint satisfaction } \\
\text { Adapts performance to the } \\
\text { needs of partners and users }\end{array}$ \\
\hline & $\begin{array}{l}\text { Public unit } \\
\text { managing } \\
\text { home nursing }\end{array}$ & & $\begin{array}{l}\text { Relationship builder } \\
\text { Systematically coordinates } \\
\text { and manages interaction and } \\
\text { knowledge exchange to reach } \\
\text { high-quality procurement } \\
\text { implementation and solve } \\
\text { problems jointly }\end{array}$ \\
\hline
\end{tabular}


In the categorization of developmental roles, the role of relationship initiator refers to the party connecting the three actors formally together and establishing the foundation for PPP development. Empirical findings demonstrate that this role is played by the public procurement unit that attracts and negotiates with the net of interested private partners and then, by bridging the needs of different actors, creates a shared understanding of procurement implementation terms and forms a contract with a suitable private partner. Thus, the role tend to requires public procurement units to promote process innovation (Knight \& Harland, 2005) in contracting and therefore the findings lend support to the view stressing the movement away from highly regulating public procurement procedures to negotiating jointly agreed goals between public and private organizations (Lawther \& Martin, 2005).

Relationship builder resembles the role of promoter (Halinen \& Salmi, 2001), although this study emphasizes activities truly fostering the development of PPPs. The purpose of these development activities is to influence the trust between the actors. In different procurement stages, by regularly exchanging knowledge with its partner, a relationship builder is suggested to reinforce mutual trust within the PPP. This type of development work thus strengthens PPPs (see Jacobson \& Choi, 2008; Jamali, 2004; Lawther $\&$ Martin, 2005). Furthermore, relationship facilitator refers to the actor who supports this development. In particular, knowledge sharing during contracting tends to support the public procurement unit in initiating the PPP, whereas follow-up tasks influence trust and thereafter PPP development during procurement implementation.

To answer the research question of how the roles change during the centralized public procurement process, the study raises the dynamics that exist between the roles actors play to reinforce to the development of PPPs, thus supporting the findings of Heikkinen et al. (2007) about role as a dynamic and emerging construct. Empirical findings show actors' rolerelated performance (DiMaggio, 1992) change during contracting and procurement implementation stages and influence the roles of the other two actors and the direction of PPP. PPPs in centralized public procurement are initiated by public procurement units that need support for their efforts from the other two actors. Initiating and facilitating roles during the contracting stage influences the PPP by increasing collaboration and knowledge exchange between actors. Thus, by establishing shared understanding of procurement implementation, playing these roles reduce the costs of contracting, mitigate the risks of complaints and clarifies contract terms (see Erridge \& Greer, 2002).

In the implementation stage of standardized raw food procurement, the public procurement unit followed the procurement and left the PPP development to the private 
supplier organization and individual public units that established trust by respecting the legal agreement between them. In home nursing procurement, the inexperience related to the management of procurement implementation, but strong substance knowledge, the procurement type and the new incentive system encouraged the three actors to contribute fairly to the development of their PPP by relying more on relational dimensions, for example, shared goals and reciprocal knowledge exchange. The findings show how the embeddedness of a partnership relationship in its context (Anderson et al., 1998) affects actors' roles and the activities through which these roles are played. Therefore, the findings support the framework of Erridge and McIlroy (2002) suggesting that public organizations need diverse strategies to manage their partnership relationships with private organizations. In addition, the findings confirm the context-specificity of roles (Knight \& Harland, 2005). Actors with similar formal position may play different behavioral roles depending on the context within which the actor has its position (e.g., Anderson et al., 1998; DiMaggio, 1992).

Empirical findings emphasize that knowledge exchange is important when actors play the three types of roles. Roles that reinforce the development of PPPs rest on different degrees of interaction and knowledge exchange depending on the procurement type. In standardized product procurement, the need for meetings and pre-negotiations during the contracting and procurement implementation stage is less than with more diversified service procurements. Organizations having less understanding concerning the procurement have a greater need to share information during the contracting and procurement implementation stages. Furthermore, knowledge exchange is perceived as strongly intertwined with trust and thus trust is reasserted to support the knowledge exchange (e.g., Hallén \& Sandström, 1988; Håkansson \& Snehota, 1995) by encouraging to bidirectional feedback.

If contrasted with the literature from PPPs and roles, this study provides detailed descriptions of roles from a relationship development perspective. In particular, the study increases the understanding of activities the roles include and their meaning with respect to PPP development, the actors playing them during different public procurement stages and how contextual factors and other actors' roles influence how these roles are played.

\section{Managerial implications}

This study has important implications for the managers of public and private organizations desiring to develop stronger PPPs in centralized public procurement and improve procurement implementation. Knowledge is provided on the roles reinforcing the 
development of PPPs and how to play these roles in different procurement contexts. This understanding helps to identify how parties affect the PPP, that is, it is important to understand the roles actors play during public procurement so that their influence is addressed. The findings of this study are particularly useful for those three actors engaging in PPPs in centralized public procurement. Thus, the managerial implications are provided to these actors individually.

\subsection{Public procurement unit}

In centralized public procurement, a public procurement unit influences the procurement implementation and the PPP through its relationship initiator role. Thus, to initiate stronger PPP, the public procurement unit should provide its partners opportunities to participate in contracting and preparing the tendering reports. In particular, pre-negotiations, for example, technical dialog with private supplier organizations requires emphasizing that they are an effective tool for hearing the anxieties of private markets, tips for preparing RFQs and therefore for bridging the needs of different actors and clarifying the terms required to implement the procurement. Negotiations help create shared understanding between the parties, thus diminishing the risk of disputes during contracting and procurement implementation stages. The dialog between the actors should though rest on a friendly and trustful atmosphere that permits honest discussion about procurement terms and specifying new, unanticipated solutions to satisfy public organizations' and society's needs.

In the procurement implementation stage, the public procurement unit influences PPP development in two ways depending on how public procurement is organized. First, if the public procurement unit primarily takes the relationship facilitator role during procurement implementation, it should establish systematic routines to follow the procurement and prospective problems that might harm the trust between the other two actors. Furthermore, the unit should guarantee through its relationship initiator role that single or multiple actors take the role of relationship builder. Through the contract, for example, the public procurement unit can influence the procurement implementation by establishing procedures for knowledge exchange, thus reinforcing the relational trust in the PPP. Second, if practical and possible, the public procurement unit should participate in PPP development, for example, by identifying specific strategic goals with the private partner that facilitate procurement implementation and exchanging knowledge accordingly. 


\subsection{Private supplier organization}

Private supplier organizations can support the efforts of public procurement units to initiate PPPs by providing important market information that helps actors reach a shared understanding of a procurement implementation and its terms. Thus, private firms should embrace the responsibility of contracting and PPP initiation and therefore participate, if possible, in negotiations with the public procurement unit. In these meetings, they should bring forward any problematic terms that might harm the PPP during the procurement implementation stage and provide other types of tips that help them, the public procurement unit and the public unit managing procurement implementation to strengthen their PPP.

In the procurement implementation stage, to perform activities fostering the development of the PPP, private firms should consider the procurement type and how it affects their efforts to build relational trust. For example, if partnership relationship relies strongly on a formal and standardized contract, respecting that contract helps build trust between the parties. Nevertheless, if public procurement is more complex and dynamic, PPP development might require relying more on relational dimensions, which tends to rest on intensive knowledge sharing between the actors. Establishing and sustaining routines that support such knowledge exchange is thus highly recommended.

\subsection{Public unit managing procurement implementation}

Public units managing procurement implementation are advised to support PPP initiation, particularly if the public procurement unit lacks important end user-related information. In particular, public units must bring forward their knowledge related to their customer not only to establish shared understanding between the three actors but also to pledge that the public interest is truly addressed during contracting. Furthermore, individual public units should pursue PPP development more strongly by systematically managing the interaction and knowledge sharing between the private partner and themselves. Such management might require public organizations to identify and develop new types of interactive relationship skills because they are traditionally described as resisting collaboration (Erridge \& Greer, 2000). 


\section{Evaluation of the study and suggestions for future research}

The trustworthiness of the study is enhanced by triangulating the theories from public procurement and managerial and intermediary roles to construct a theoretical categorization identifying the roles reinforcing the development of PPPs. Furthermore, the research setting researched PPPs and their contexts, the gathered data and how they are transformed and triangulated into proposed theoretical and managerial implications (Symon \& Cassell, 2012) - is thoroughly described and justified, which aids the reader to understand and review the logical reasoning of the researcher. In addition, the researcher's interpretations are supported by direct quotes from key informants' interviews and by giving the informants and the peers of the researcher an opportunity to review the transcript of the paper.

If the limitations of this study are examined, they should be analyzed in the context of the selected research phenomenon. The purpose of this paper related to developmental roles and harmful roles were largely ignored. Nevertheless, despite this purpose, empirical material yields hints from private partners taking the role of supervisor who monitors the fairness of bid process, which is manifested rather negatively through complaints. Aligned with Komulainen et al. (2013), research related to roles inhibiting PPP development is thus considered important. Furthermore, the findings present that the public procurement context affects how actors play their roles. Therefore, different procurement contexts require exploring to understand more the roles that either promote or inhibit PPPs. In particular, research that explores PPPs in a centralized service setting has largely remained an underresearched topic that needs to be investigated to increase our knowledge about PPPs.

\section{Acknowledgements}

This research is part of the BRIIF research project funded by Smart Procurement Programme of Finnish Funding Agency for Innovation (TEKES) whose financial support is gratefully acknowledged. Gratitude is also expressed to the Finnish Cultural Foundation for their financial support to this research and to the interviewees for their time and effort. I addition, I would like to thank the three anonymous reviewers for their insightful comments, which significantly improved this article. 


\title{
Appendix A Themes of the thematic interviews
}

\author{
Background information
}

Interviewee's title and responsibilities

\section{Procurement}

Procurement type and its characteristics

Factors engendering procurement

Procurement goals

\section{Contracting stage}

Procurement method

Contracting process

Actors involved and their responsibilities

Activities involving collaboration and their benefits

Contracting challenges and how to overcome them

\section{Procurement implementation stage}

Procurement implementation practices

Coordination of procurement implementation

Actors involved and their responsibilities

Activities involving collaboration and their benefits

Procurement implementation challenges and how to overcome them

\section{References}

Anderson, H., Havila, V., Andersen, P., \& Halinen, A. (1998). Position and role-conceptualizing dynamics in business networks. Scandinavian Journal of Management, 14(3), 167-186.

Arksey, H., \& Knight, P. T. (1999). Interviewing for social scientists: An introductory resource with examples. London: Sage.

Ashforth, B. (2000). Role transitions in organizational life: An identity-based perspective. New Jersey: Lawrence Erlbaum Associates.

Batonda, G., \& Perry, C. (2003). Approaches to relationship development processes in inter-firm networks. European Journal of Marketing, 37(10), 1457-1484.

Biddle, B. J. (2013). Role theory: Expectations, identities and behaviors. New York: Academic Press.

Biddle, B. J. (1986). Recent development in role theory. Annual Review of Sociology, 12, 67-92.

Biernacki, P., \& Waldorf, D. (1981). Snowball sampling: Problems and techniques of chain referral sampling. Sociological Methods and Research, 10(2), 141-163.

Brown, T. L., \& Potoski, M. (2003). Contract-management capacity in municipal and county governments. Public Administration Review, 63(2), 153-164.

Caldwell, N., Walker, H., Harland, C., Knight, L., Zheng, J., \& Wakeley, T. (2005). Promoting competitive markets: The role of public procurement. Journal of Purchasing and Supply Management, 11(5), 242-251.

Chou, J., \& Pramudawardhani, D. (2015). Cross-country comparisons of key drivers, critical success factors and risk allocation for public-private partnership projects. International Journal of Project Management, 33(5), 1136-1150.

Cousins, P., Lamming, R., Lawson, B., \& Squire, B. (2008). Strategic supply management: Principles, theories and practice. Essex: Pearson Education.

Denzin, N. K. (1978). The research act: A theoretical introduction to sociological methods. New York: McGraw Hill. 
DiMaggio, P. (1992). Nadel's paradox revisited: Relational and cultural aspects of organizational structure. In N. N. Nohria, \& E. R. G. Eccles (Eds.), Networks and organizations: Structure, form and action (pp. 118-142). Cambridge, Boston: Harvard Business School Press.

Dubois, A., \& Fredriksson, P. (2008). Cooperating and competing in supply networks: Making sense of a triadic sourcing strategy. Journal of Purchasing and Supply Management, 14(3), 170-179.

Dubois, A., \& Gadde, L. E. (2002). Systematic combining: An abductive approach to case research. Journal of Business Research, 55(7), 553-560.

Dwyer, F. R., Schurr, P. H., \& Oh, S. (1987). Developing buyer-seller relationships. Journal of Marketing, 51(2), 11-27.

El-Ansary, A., \& Stern, L. W. (1992). Marketing Channels. Englewood Cliffs: Prentice-Hall.

Erridge, A. (2007). Public procurement, public value and the Northern Ireland unemployment pilot project. Public Administration, 85(4), 1023-1043.

Erridge, A., \& Greer, J. (2002). Partnerships and public procurement: Building social capital through supply relations. Public Administration, 80(3), 503-522.

Erridge, A., \& Greer, J. (2000). Policy network analysis of UK central government civil procurement. Public Policy and Administration, 15(4), 25-49.

Erridge, A., \& McIlroy, J. (2002). Public procurement and supply management strategies. Public Policy and Administration, 17(1), 52-71.

Essig, M., \& Batran, A. (2005). Public-private partnership - Development of long-term relationships in public procurement in Germany. Journal of Purchasing and Supply Management, 11(5), 221231.

Ford, D., Gadde, L. E., Håkansson, H., Lundgren, A., Snehota, I., Turnbull, P., \& Wilson, D. (1998). Managing Business Relationships. London: Wiley.

Gidman, P., Blore, I., Lorentzen, J., \& Schuttenbelt, P. (1995). Public-private partnerships in urban infrastructure services. UMP Working Paper Series No. 4, UNDP/Habitat/World Bank, Nairobi.

Gutek, B. A., Groth, M., \& Cherry, B. (2002). Achieving service success through relationships and enhanced encounters. Academy of Management Executive, 16(4), 132-144.

Guzmán, F., \& Sierra, V. (2012). Public-private collaborations: Branded public services? European Journal of Marketing, 46(7/8), 994-1012.

Håkansson, H., \& Snehota, I. (1995). Developing Relationships in Business Networks. London: Routledge.

Halinen, A., \& Salmi, A. (2001). Managing the informal side of business interaction: Personal contacts in the critical phases of business relationships. Proceedings from the $17^{\text {th }}$ Annual IMP Conference, 9-11 September, Oslo, Norway.

Halinen, A., \& Törnroos, J.-A. (2005). Using case methods in the study of contemporary business networks. Journal of Business Research, 58(9), 1285-1297.

Hallén, L., \& Sandström, M. (1988). Relationship atmosphere in international business. Proceedings of $4^{\text {th }}$ Annual IMP Conference, 7-9 September, Manchester, United Kingdom.

Havila, V., Johanson, J., \& Thilenius, P. (2004). International business-relationship triads. International Marketing Review, 21(2), 172-186.

Heikkinen, M. T., Mainela, T., Still, J., \& Tähtinen, J. (2007). Roles for managing in mobile service development nets. Industrial Marketing Management, 36(7), 909-925.

Hodge, G. A., \& Greve, C. (2007). Public-private partnerships: An international performance review. Public Administration Review, 67(3), 545-558.

Holmen, E., \& Pedersen, A. C. (2003). Strategizing through analyzing and influencing the network horizon. Industrial Marketing Management, 32(5), 409-418.

Holmlund, M., \& Törnroos, J.-A. (1997). What are relationships in business networks? Management Decision, 35(4), 304-309.

Jacobson, C., \& Choi, S. O. (2008). Success factors: Public works and public-private partnerships. International Journal of Public Sector Management, 21(6), 637-657.

Jamali, D. (2004). Success and failure mechanisms of public private partnerships (PPPs) in developing countries: Insights from the Lebanese context. International Journal of Public Sector Management, 17(5), 414-430.

Järvensivu, T., \& Törnroos, J.-Å. (2010). Case study research with moderate constructionism: Conceptualization and practical illustration. Industrial Marketing Management, 39(1), 100-108. 
Kanter, R. M. (1994). Collaborative advantage: The art of alliances. Harvard Business Review, 72(4), 96-108.

Karjalainen, K. (2011). Estimating the cost effects of purchasing centralization - Empirical evidence from framework agreements in the public sector. Journal of Purchasing and supply Management, 17(2), 87-97.

Kernaghan, K. (2003). Integrating values into public service: The values statement as centerpiece. Public Administration Review, 63(6), 711-719.

Klijn, E. H., \& Teisman, G. R. (2003). Institutional and strategic barriers to public-private partnership: An analysis of Dutch cases. Public Money and Management, 23(3), 137-146.

Knight, L., \& Harland, C. (2005). Managing supply networks: Organizational roles in network management. European Management Journal, 23(3), 281-292.

Komulainen, H., Mainela, T., \& Tähtinen, J. (2013). Intermediary roles in local mobile advertising: Findings from a Finnish study. Journal of Marketing Communications, 1-15.

Krapfel, R. E. (1985). An advocacy behavior model of organizational buyers' vendor choice. Journal of Marketing, 49(4), 51-59.

Kuusniemi-Laine, A., \& Takala, P. (2007). Julkisten hankintojen käsikirja. Edita.

Kwak, Y. H., Chih, Y., \& Ibbs, C. W. (2009). Towards a comprehensive understanding of public private partnerships for infrastructure development. California Management Review, 51(2), 5178.

Larson, P. D. (2009). Public vs private sector perspectives on supply chain management. Journal of Public Procurement, 9(2), 222-247.

Lawther, W. C., \& Martin, L. L. (2005). Innovative practices in public procurement partnerships: The case of the United States. Journal of Purchasing and Supply Management, 11(5), 212-220.

Levinson, D. J. (1959). Role, personality and social structure in the organizational setting. Journal of Abnormal and Social Psychology, 58(2), 170.

Li, B., Akintoye, A., Edwards, P. J., \& Hardcastle, C. (2005). Critical success factors for PPP/PFI projects in the UK construction industry. Construction Management and Economics, 23(5), 459471.

Li, M., \& Choi, T. Y. (2009). Triads in services outsourcing: Bridge, bridge decay and bridge transfer*. Journal of Supply Chain Management, 45(3), 27-39.

Lian, P. C. S., \& Laing, A. W. (2004). Public sector purchasing of health services: A comparison with private sector purchasing. Journal of Purchasing and Supply Management, 10(6), 247-256.

Lindskog, H., Brege, S., \& Brehmer, P. O. (2010). Corruption in public procurement and private sector purchasing. Organisational Transformation and Social Change, 7(2), 167-188.

Madhavan, R., Gnyawali, D. R., \& He, J. (2004). Two's company, three's a crowd? Triads in cooperative-competitive networks. Academy of Management Journal, 47(6), 918-927.

Merton, R. K. (1957). The role-set: Problems in sociological theory. British Journal of Sociology, $8(2), 106-120$.

Miles, M. B., \& Huberman, A. M., (1994). Qualitative data analysis: An expanded sourcebook. Thousand Oaks: Sage.

Mintzberg, H. (1980). The nature of managerial work. Englewood-Cliffs: Prentice-Hall.

Möller, K., Rajala, A., \& Svahn, S. (2005). Strategic business nets - Their type and management. Journal of Business Research, 58(9), 1274-1284.

Montgomery, J. D. (1998). Toward a role-theoretic conception of embeddedness. American Journal of Sociology, 104(1), 92-125.

Nätti, S., Pekkarinen, S., Hartikka, A., \& Holappa, T. (2014). The intermediator role in value cocreation within a triadic business service relationship. Industrial Marketing Management, 43(6), 977-984.

Parker, D., \& Hartley, K. (2003). Transaction costs, relational contracting and public private partnerships: A case study of UK defence. Journal of Purchasing and Supply Management, 9(3), 97-108.

Peng, M. W., \& Ilinitch, A. Y. (1998). Export intermediary firms: a note on export development research. Journal of International Business Studies, 29(3), 609-620.

Perrone, V., Zaheer, A., \& McEvily, B. (2003). Free to be trusted? Organizational constraints on trust in boundary spanners. Organization Science, 14(4), 422-439. 
Purchase, S., Goh, T., \& Dooley, K. (2009). Supplier perceived value: Differences between businessto-business and business-to-government relationships. Journal of Purchasing and Supply Management, 15(1), 3-11.

Rainey, H. G., \& Bozeman, B. (2000). Comparing public and private organizations: Empirical research and the power of a priori. Journal of Public Administration Research and Theory, 10(2), 447-469.

Rees, P., \& Gardner, H. (2003). Best value, partnerships and relationship marketing in local government. International Journal of Nonprofit and Voluntary Sector Marketing, 8(2), 143-152.

Salo, A., Tähtinen, J., \& Ulkuniemi, P. (2009). Twists and turns of triadic business relationship recovery. Industrial Marketing Management, 38(6), 618-632.

Simmel, G. (1950). Quantitative aspects of the group. In G. Simmel, \& K. H. Wolff (Eds.), The sociology of Georg Simmel (pp. 87-177). New York: Free Press.

Smyth, H., \& Edkins, A. (2007). Relationship management in the management of PFI/PPP projects in the UK. International Journal of Project Management, 25(3), 232-240.

Snow, C. C., Miles, R. E., \& Coleman, H. J. (1993). Managing $21^{\text {st }}$ century network organizations. Organizational Dynamics, 20(3), 5-20.

Stake, R. E. (1995). The art of case study research. Thousand Oaks: Sage.

Symon, G., \& Cassell, C. (2012). Assessing qualitative research. In G. Symon, \& C. Cassell (Eds.), Qualitative organizational research: Core methods and current challenges (pp. 204-223) London: Sage.

Tanner Jr., J. F. (1999). Organizational buying theories: A bridge to relationships theory. Industrial Marketing Management, 28(3), 245-255.

Thibaut, J. W., \& Kelley, H. H. (1959). The social psychology of groups. New York: John Wiley \& Sons.

Trautmann, G., Bals, L., \& Hartmann, E. (2009). Global sourcing in integrated network structures: The case of hybrid purchasing organizations. Journal of International Management, 15(2), 194 208.

Turner, R. H. (1990). Role taking: process versus conformity. In D. Brissett, \& C. Edgley (Eds.), Life as theater: A dramaturgical sourcebook (pp. 85-100). New Jersey: Transaction Publishers.

van Iwaarden, J., \& van der Valk, W. (2013). Controlling outsourced service delivery: Managing service quality in business service triads. Total Quality Management and Business Excellence, 24(9-10), 1046-1061.

Weiss, F. (1993). Public procurement in European community law. London: Athlone Press.

Williams, P. (2002). The competent boundary spanner. Public Administration, 80(1), 103-124.

Wilson, K., \& Millman, T. (2003). The global account manager as political entrepreneur. Industrial Marketing Management, 32(2), 151-158.

Zhang, X. (2005). Critical success factors for public-private partnerships in infrastructure development. Journal of Construction Engineering and Management, 131(1), 3-14.

Zou, W., Kumaraswamy, M., Chung, J., \& Wong, J. (2014). Identifying the critical success factors for relationship management in PPP projects. International Journal of Project Management, 32(2), $265-274$. 